\title{
CLASS ANALYSIS AND SOCIAL MOVEMENT THEORY: TOWARD A SYNTHESIS*
}

\section{Scott G. McNall}

University of Kansas

Mid-American Review of Sociology, 1986, Vol. XI, No. 2:3-28

Much time and energy has been devoted to describing the class structure of modern capitalist societies (Wright, 1984, 1985; Meiksins, 1986; McKenzie, 1982; Oppenheimer, 1985; Ehrenreich and Ehrenreich, 1978). Boundary questions--about just how many classes there really are, or whether or not white-collar workers do or do not occupy contradictory class locations, or whether or not members of the professional managerial classes are proto-capitalists or not--are not, in and of themselves, significant. The participants in such debates are aware that such questions are directly related to political strategy, and that this relationship is significant. If white-collar, service workers are proletarianized, then the potential for liaisons between the traditional and the "new" working classes is enhanced, and we should capitalize on this fact by pointing out to people the similarities in their positions.

Divisions have been drawn between classes with varying degrees of sophistication. Those working in a Marxist tradition have exhibited the greatest sensitivity, for they understand that the element of exploitation is key in deciding who is, and who is not, a member of which potential class formation. A class society is, by definition, one in which one group appropriates the surplus labor of another. Class conflict exists, and classes stand in opposition to one another, because of exploitation.

However, we know that there is a great deal of diversity among those who sell their labor power. We know that people do not respond to exploitation in precisely the same way, even members of what we would think of as uniform class formations. And furthermore, we are aware that many contemporary movements have been grounded in ethnicity or religion, as opposed to social class. It would seem, then, that the question we ought to ask has less to do with boundaries, than with the conditions under

* Adapted from Rhonda Levine and Jerry Lembcke, Editors, Recapturing Marxism: An Appraisal of Recent Trends in Sociology Theory. 1987, Praeger Publishers, a division of Green Press, Inc. 
which people recognize themselves as members of a class, and the which pelass movements are likely to succeed. I he the question can help us arrive at a better hope to show that this question can help us arrive at a better understanding of the kind of political strategies called for. After all, our labels have little to do with how people actually define their life circumstances, or whether or not they mobilize. Classes are (as Marx said) created over time, by human actors who define themselves in active opposition to other groups in the society. By themselves in active opposition to other groups in, then, class cannot be defined in terms of occupational position or skills. Class is simultaneously structure, organization, and ideology. Let us examine in detail what this means, and its political implications.

\section{DEFINING CLASS ${ }^{1}$}

How does a class become a class for itself? In what is class consciousness rooted, and what role does it play in mobilizing consciousness rooted, and what role dince the days of the economic people? We have come a long way since the days of the economic determinists, when class was seen as a simple reflection of one's economic position. E.P. Thompson in particular expanded our understanding of class formation. As he demonstrated in The Making of the English Working Class (1963:11), classes are emergent.

If we stop history at a given point, then there are no classes but simply a multitude of individuals with a no classes but simplences. But if we watch these men over an a dequate period of social change, we observe over an adequate, period of social chan ideas, and their patterns in their relationships, their ideas, institutions. Class is defined by men as they live their own history, and, in the end, this is its only definition.

A class, in Thompson's (1978:295) view, is a "very loosely defined A class, in Thompson's (1970 same categories of interests, social body of people who share the same categoriso have a disposition to experiences, traditions and the themselves in their consciousness in behave as a class, to define themselves in their "consciousnefined relation to other groups of people in class ways." Class is defined in cultural terms, and in opposition to other social groups. People must see and describe themselves as different. As Thompson further argues (1978:8), through people's lived experiences, confrontations with the world at large and attempts to make sense out of those confrontations, classes emerge, and with them a willingness to act on the basis of class. "What we mean," he says, "is willingness to act on the basis of class. "Whings, which give rise to that changes take place within social beings, which give rise to changed experience: and this experience is determining, in the sense that it exerts pressures upon the existent social consciousness, proposes new questions, and affords much of the material which the more elaborated intellectual exercises are about."

Thompson has been criticized on both empirical and theoretical grounds for his view of the process of class formation, and his idea about when the British working class comes on the scene (Calhoun, 1982; Hobsbawm, 1984a). Two issues involved in this debate seem central for understanding class mobilization: the weight one gives to the rational class actor (agents) versus the social structure, and the extent to which one emphasizes cultural and ideological variables as opposed to "economic" ones.

The agency-structure debate has been pursued at length by Thompson in direct opposition to the ideas of Louis Althusser $(1968,1970)$ and Perry Anderson $(1974,1980)$. Briefly, Althusser, arguing from a structural position, rejected the notion of active human agents; people were simply the "bearers" of social structure. Anderson, in opposition to Thompson, said that modern history was best understood as the unfolding of the contradictions within society. If agents played a role, it was only with the rise of modern revolutionary movements. Thompson, in a pointed attack on the entire structuralist school, argued strongly for human agency; history was consciousness, was goal-directed actors pursuing their interests. Douglas Porpora (1985), in an attempt to resolve the debate, suggested that crises may be brought about, as Anderson claims, by structural contradictions in society, and that human agents may react to these changes, but in unpredictable ways. Although Porpora is correct in giving structure its due, it is important to consider how class conscious actors can generate within a system the very crises or contradictions that Anderson takes às given. This is one of the strengths of Thompson's position: he assumes that crises can be generated by active human agents. But even here a caveat is in order, for people's actions do not always produce the results they hoped for.

Craig Calhoun (1982) has also criticized Thompson for not being Marxist enough in his analysis of the formation of the British working class. He says that Thompson failed to deal with people's objective relationship to the means of production. Calhoun argues that radicalism, which Thompson attributed to the working class, was actually rooted in artisanal communities. This is not to reduce class to simple economic relations, but to argue (as I do) for an understanding of class as culture, structure, and social relationships. Calhoun's British artisans mobilized, not only because they understood that they must do so to protest the loss of a way of life, but because they belonged to true communities. To 
mobilize, "people must have strong emotional ties with each other, a faith in their strength, and an identification with the collectivity in which they are to act" (Calhoun, 1982:136). William G. Roy, in in which they are to act" (Calhoun, 1982:136). Willam work of such neo-Marxists as Calhoun, the traditional Marxian perspective has been altered.

Neo-Marxists disagree with advocates of economic determinist versions of Marxism who assert that collective action is motivated by class-based interests. The historical record is too full of examples of collective action propelled by religious, ethnic, regional, ction prostas relationships to sustain nationalistic, and other cross-class relationships to sustain such an assertion. They alternatively propose that collective action is historically decisive to the extent that it is rooted in class relationships, which analytically links the causes and consequences of class action (1984:497498).

Classes, then, can even affect the mode of production. The social relations of production (a part of the mode of production), and sometimes even the social forces of production, are modified as and sometimes even the social forces of production, are mode ma to protect a way of life, a way of working and living. In organizing, in conf ronting the world in which they live, people develop class consciousness. Consciousness grows out of action. However, this consciousness is not created anew, but refined.

The importance of the lived experiences of people as the "material" out of which classes are constituted has been clearly demonstrated by, among others, Herbert Gutman (1973). Gutman points out that language, stories, and ideas of harmony and brotherhood make a people, and hence a class, unique. Ideology enters significantly into the formation of classes (see Sewell, 1985, for "independent" structuring role of ideology). Ideologies are no more stagnant than any other part of social reality (Snow, et al., 1986). As Ron Aminzade (1981) has shown in his study of French artisans, they, like Calhoun's English artisans, were a consistently radical force in preindustrial France precisely because of their non-economic interests. These interests were expressed, argued over, sharpened and defined, and grew out of informal gatherings and associations. In short, worker capacity for political and economic mobilization stemmed from a way of life, embracing both economic position and ideas about such things as the work process and the nature of the family.
Now, if ideology is as central an element as material force in shaping class action, then it deserves as much attention in crafting political strategy as any other element. Moreover, we need to give our attention to those mechanisms in contemporary society that allow for the expression and mobilization of ideology, as well as those factors that inhibit it. Here I wish to emphasize the fact that in American society one of the ways people have learned about the nature of their oppression, and learned to articulate the values they wish to protect, is through their participation in class organizations. In mobilizing, in trying to actually change the economic and political system, people create themselves as a class. Politics, broadly defined, is not secondary but central to the process of class formation in American society. More specifically, political parties have of ten served as distinct class organizations.

Theda Skocpol (1980) has appropriately called our attention to American political parties as a means through which contesting groups both express and attempt to act on the basis of class interests. She has been criticized (Levine, 1985; Quadagno, 1984), however, for ignoring social class and for failing to examine the means by which class contradictions become imbedded in the modern state. Skocpol tends to see party and state as independent systems, and to see neither party nor state policy as the result of class struggle. I would argue that it is of ten via the political party that class contradictions become imbedded within the state system. Class, party, and state are intimately linked. State structure and state policy are determined by the class contradictions imbedded within them (Poulantzas, 1978). Among the western industrialized countries the political party has been, and can still be, a means for articulating and shaping class consciousness, which in turn forms the nature and structure of the modern state.

It would be foolish to suggest that American political parties represent distinct social classes. Groups of ten compete for dominance within the party (in the case of the Democrats, unions, industrialists, and ethnic groups, to name but a few), in order to shape national or state policy. Much of the struggle between classes thus occurs as a result of their attempt to achieve hegemony within a party. The political process also masks class struggle. One could describe this process as a struggle over organizational capacities; in fact, as I will argue, the attempt of a class to create itself, and to develop class consciousness, is dependent in large part on its organizational capacities (Prezworski, 1977). This position is not unlike that which Marx (1852/1919:109) articulated in The Eighteenth Brumaire. 
In so far as millions of families live under economic conditions of existence that separate their mode of life, their interests, and their culture from other classes, and put them in hostile opposition to the latter, they form a class. In so far as there is merely a local interconnection among the small peasants, and the identity of their interests begets no unity, no national union, and no political organization, they do not form a class. They are consequently incapable of enforcing their class interest in their own name, whether through parliament or through convention.

A group's ability to become a class is affected by internal divisions, or structural capacities, and the overall nature of the class structure at any given historical moment. A diagram (see Figure I) clarifies the relationship between the variables. At any given time, the class structure of a society is made up of diverse economic locations or positions. Some people are white-collar workers, some blue-collar, others are managers and capitalists. Each of these groups possesses different structural capacities for mobilizing as a class, and these are intimately related to their organizational capacities. For instance, miners have traditionally had a high degree of interaction, have seen themselves as occupying a distinct position in society, and as a result have acted in concert. Many service workers, on the other hand, are widely separated from one another, do not live and work in the same communities, and tend not to act in unison. Furthermore, people's structural capacities might be affected by the fact that they are divided from one another by religion or ethnicity. Class consciousness, in turn, is determined by people's organizational and structural capacities, and their attempt to act as a class.

Class organizations loom large in this model as a factor, not only in shaping class consciousness, but in determining whether or not a class will be successful--become a class in and for itself. In this model there is no such thing as false consciousness. Structural conditions and class capacities combine in such a way as to produce strategies which may or may not be successful in shaping state policy. People may choose strategies which isolate them from other classes, mobilize powerful elites against them, or allow their movement to be defused at the ballot box by the dominant parties endorsing elements of their platforms. In short, rational actors sometimes make strategic mistakes. (The conditions under which they might make fewer mistakes are treated below.)

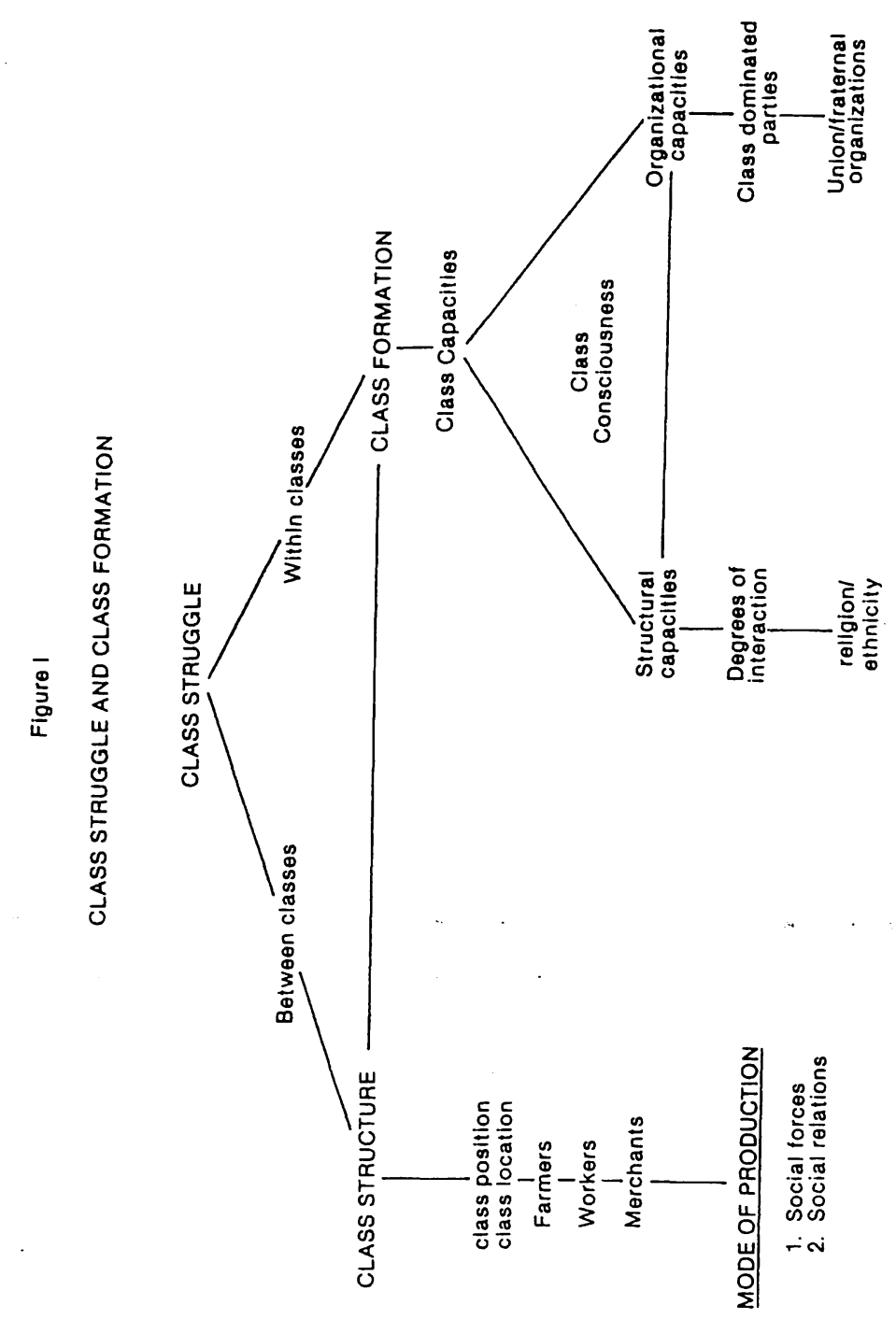


Marxist class theory is an invaluable tool for understanding why class conflict exists, and for keeping our attention focused on the element of exploitation. However, traditional class theory has not helped us greatly to understand the processes by which people do or do not mobilize as classes, and why they succeed or fail to do or do not mobilizes as autonomous classes. I believe that our create themselves as autonomous classes. by conceptualizing class formation as a social movement.

\section{CLASS MOVEMENTS AS SOCIAL MOVEMENTS}

\section{Sources of Solidarity and Bases of Mobilization}

Something other than sheer economic distress must be invoked to account for the rise of class movements. Usually, challenges to traditional values and a sense of community cause people to take up arms. To take an example from nineteenth century American history, hundreds of thousands of farmers in the North and South joined the Farmers' Alliance in an attempt to halt North and South join of corporate America over their lives. Steven Hahn (1983) in his study of those yeoman farmers from the Hahn (1983) in his studed, said that it was because of changed social relations. Upcountry farmers, were, in Hahn's view, reacting to a law that would have required them, at considerable to a new law that would have required them, at coning freely, expense, to keen done for decades. This new law acted as a catalyst to as had been done for decades. disruptive social change" (271). The proposed changes in grazing rights led to the fear that their whole lives were being subordinated to the capitalist market system. The Alliance, and then the Populist Party which grew out of it, provided a means by which farmers could articulate threatened values and stand against challenges to their traditional ways of life. As with early nineteenth century artisans on the Continent, a threat to traditional value systems provided the impetus for mobilization.

The immediate social world of class actors plays a decisive role in determining whether or not they will become involved in a movement, ignore it, or abandon it at a later stage. As Mark movement, ignore it, or abandon "Actors do not behave or decide as atoms outside a social context, nor do they adhere slavishly to a atoms outside a social context, nor do the intersection of social categories they happen to occupy. Their attempts at purposive categories the action are instead embedded in concrete, ongoing systems of relations." In the case of Hahn's Georgia yeomen, they abandoned
the Alliance because ties of kith and kin reasserted themselves when the movement foundered. It is something of a paradox, then, that although people may mobilize on the basis of traditional values, and becöme radicalized as a result, of ten ties to local communities and age-old values can limit their possibilities. Sometimes people cannot transcend the localism that served to fire the original movement. In addition, as Mary Ann Clawson (1985:674) has so ably demonstrated in her study of fraternal organizations at the turn of the century, a substantial number of people were and are embedded in organizations that act to "deconstruct class as a basis for organization, mobilization, and solidarity...." To overcome such limiting contexts people must be educated, and must understand that they need to act as a class. How does this come about?

\section{Strategy and Creative Escalation}

One of the ways in which people learn to act in concert is through involvement in a social movement. The social, or class movement, serves several important functions. Movements help to translate grievances into a sense of injustice, a key element, as Barrington Moore (1978) noted, in sustaining mobilization. People must come to feel that traditional social rules have been violated, that injustices have been created, and that they can do something about it. A class movement, then, must possess an effective protest ideology, one which can explain past failure, current defeats, and provide hope for the future.

Though people come to a movement with definite expectations, they also develop new ones as a result of confronting the established political and economic order. Lawrence Goodwyn (1978) said that nineteenth century American farmers developed a counter-ideology as a result of their involvement in the Farmers' Alliance. That is, they met together, discussed their grievances, developed ideas about how to deal with their economic plight, and tried to put them into operation by forming economic cooperatives. Having formed cooperatives they found merchants and bankers allied against them, because their efforts threatened capital's control over labor power, marketing, and distribution systems. Farmers learned who their enemies were, and what they were up against, because they tried to change the system. In this century, coal miners who mobilized against owners, and found themselves confronted with hired thugs protected by state and local governments, or even had public armies turned against them, learned that large capital and the state walked hand-in-hand.

The strategies that any given group of people use are seldom simple or limited to one technique, unless goals are very limited. 
For instance, a sit-down strike may be a means to achieve immediate wage concessions, but it will not be the means by which the working class comes to control the means of production. The history of groups moving toward dominance are replete with examples of first one, and then another strategy, as the group inches closer to its final purpose. In the late nineteenth century, American cotton farmers found themselves facing ruin. The price of cotton had dropped to its lowest point since the Civil War, and many lived in conditions of debt peonage. Those farmers who composed the Texas Alliance first tried to work out simple trade agreements with local merchants; then, when the merchants would not cooperate, they tried to form their own stores, mills, and cotton gins. Finding themselves again challenged, they tried to market their cotton by themselves; that effort was followed by a joint-note program designed to free them from the lien system. They staged a boycott against the Jute Trust (those who produce the jute used to bag the raw cotton); and when that failed finally, they formed a political party (Barnes, 1984:106-107).

There is an important relationship between strategy, creative escalation, learning, and success (Barnes, 1984; McAdam, 1983). Normally, it is the responsibility of the leadership of a social movement organization to promulgate an ideology which will explain failure, or externalize blame (Barnes, 1984:98). That is, if a group is blocked in its attempts to win concessions as the result of a sit-down strike, or its withholding of rent payments, or rioting, blame must be laid at the door of those the group is opposing; for example, the opposition had the support of the local police, or the "management" was negotiating in bad faith, or landlords do not care about people. If a strategy does not work, a group must move to another level, to creatively escalate the battle. Doug McAdam (1983), in his analysis of the 1960's civil rights movement, described a process by which the leadership of these groups consciously adopted new strategies when morale appeared to be waning. There was a decision to state protests in areas where the police were known for their violent behavior so that civil rights protestors and groups would gain national support, and so that they could make the implicit and explicit point that this was a racist society. The success of new strategies is highly dependent on learning, however. Members of groups must know and understand why an old strategy has failed, and why new ones must be employed.

Creative escalation has its risks; it can create schisms within an organization. In class movements, participants might not be willing to choose a revolutionary path, if the struggle appears long, difficult, and results problematic. Without organized learning they might just as easily choose a reformist course. There is no magic formula, but one can say that strategies which are debated by the rank and file and are clearly understood by them are those likely to be supported. This is a major reason why "political" education has played such a prominent role among revolutionary cadres. The Vietcong, for instance, talked about the lessons to be learned from previous encounters, and these discussions served to cohere the group and boost morale.

Escalation also poses another type of threat to the organization. Escalation can cause powerful outside elites to mobilize against the group in question (Schwartz, 1976). Elites, too learn during an extended struggle (McAdam, 1983). In the case of the civil rights movement, some southern law enforcement of ficials found that a strategy of violent response was counterproductive. Instead, they chose to adhere to the law, and enforce it in a nondiscriminatory pattern. In short, they put the civil rights leaders in positions where they either acted peacefully, and hence def used the movement, or acted violently themselves, and hence lost support they needed to gain concessions. A group must be in a position to choose courses of action which run the thin line between mobilizing powerful opposition groups, and having their own movement die for a lack of forward movement. The importance of both organization and learning looms even larger when we consider the issue of the rational actor.

\section{The Rational Class Actor: Selective Incentives and Moral Suasion}

The extreme position in the rational actor debate is taken by Mancur Olson (1965:2) who argued that there is little reason to expect political organizations, unions, or social movements to act on the basis of the specific interests of the individuals who make up the movement, or to have individuals act on the basis of the collective. On the contrary, "unless the number of individuals in a group is quite small, or unless there is coercion or some other specific device to make individuals act in their common interest rational self-interested individuals will not act to achieve their common or group interests." Were this true, there would be little reason to believe that people could constitute themselves, and act, as a class. Yet the perspective deserves examination rather than simple rejection.

Much of the controversy surrounding Olson's theory revolves around the issue of solidarity versus selective incentives (see Jenkins, 1983, for a summary of the debates). Anthony Oberschall (1978), as well as John McCarthy and Mayer Zald (1973) have 
argued that one of the primary reasons people mobilize is to secure bem movement entrepreneurs, or benefits made avallable to them by movement entrepreneurs, or benefits generated by the movement through political action. Bruce Fireman and William Gamson (1979:10), in a spirited critique of this position, argued that although the "amount of resources at the discretion of potential constituents, the degree of previously existing organization among potential constituents. . . and--overall-the structure of the political economy constraining the mobilization and wielding of resources. . " are significant, the impact of these factors is of ten mitigated by the desire to achieve a collective good In short, solidarity and moral vision count. Social movements, and again by implication class movements, must:

offer the collective incentives of group solidarity and commitment to moral purpose. Group solidarity and purposive incentives are collective in that they entail the fusion of personal and collective interests. Movement 作 internalized values and sentiments as well as calculations of self-interest. The major task in mobilization, then, is to generate solidarity and moral commitment to the broad collectivities in whose name movements act (Jenkins, 1983:537-538).

Bert Klandermans (1984:592) put the matter slightly differently. He, too, is uncomfortable with the strong version of Olson's argument. Klandermans found that people's willingness to participate in strikes depended, in large part, on their belief that other workers would participate, and that there was a reasonable chance of success. "Adequate diffusion of knowledge of the collective good is the cornerstone," said Klandermans, "of every mobilization campaign."

John A. Hanningan (1985:441), in his review of the work of Alain Touraine and Manuel Castells in social movement theory, also argued that selective incentives must "be buttressed by the collective incentives related to group solidarity and commitment to a moral purposes, or collective agreements about means, grow out of involvement in the movement itself.

One must combine a rational-actor perspective with an understanding that people may join a movement for nonins also realize that an image of the collective good and solidarity can grow out of action. Of course there will be those who join a cause because they believe benefits will be forthcoming, and who readily exit when they are not. The longer people are in an organization, the tighter the networks that brought them together in the first place, the more probably they will come to identify with the collective, and be willing to sacrifice short-term individual interests for the long-term gains of the group. People, then, can make rational decisions to participate in collective actions to produce collective goods from which they will benefit.

Yet another caveat concerning the rational-actor perspective must be introduced. Rational actions sometimes have unintended consequences, and what may be rational in the short-term, whether for the individual or the class, may not be rational in the long run. Individually rational decisions may be a collective irrationality. Let us take an example to clarify the point. Calhoun (1982:229), in his treatment of Marx's designation of the working class as potentially revolutionary, noted that Marx was correct to argue that only by behaving as a revolutionary class and acting in concert could working men and women achieve their goals. But, he says, Marx was wrong to assume that "class must supersede all other collectivities for the workers, and that those interests which they had in common as members of the working class must become their exclusive interests, and that, therefore, it was individually rational for each worker to participate in the collectively rational overthrow of capitalist domination by the working class." Calhoun argued that it was rational for the nineteenth century British working class to choose options which produced immediate benefits. To the extent that workers, or any other group, had options other than engaging in pure class action--which could and did produce dire consequences--it was individually rational to pursue low-cost goals, even when the results did not advance the class as a whole (collectively irrational).

\section{Speed of Movement Formation, Size, and Power}

If mobilization for action is rapid, the organizational structures necessary for learning to take place are weak or absent. If a movement is large in size (which a class movement must of necessity be), learning is inhibited. Clauss Offe (1985) has provided us with a detailed statement of the relationship between individual interests and the propensity of a group of people to mobilize and engage in prolonged action, which we will modify for our purposes. Offe developed his model on the basis of a discussion about unions, and argued that there was a contradictory relationship between size of an organization and the power it has to affect the larger environment. That is, the greater the size of a 
group, the less the propensity for any given individual to be sufficiently motivated to sacrifice him/herself for the group's goals. In the case of a large union, a member might not see why it was in his/her direct interests (either economic, political, or organizational, in the sense that support would strengthen the organization and lend credibility to its demands) to act at the union's behest. For a union or any other form of class organization to be successful, people must be educated by the organization in the movement culture, and/or ideology, otherwise they are not likely to support its long-term goals and purposes. Likewise, if the time between recruitment and attempted mobilization is short, then the likelihood of a group's success is diminished, because they will not have had time to develop a movement culture and/or members will not understand the organizational policies or tactics that lead to discipline. (As will be seen below in our discussion of Piven and Cloward, this means that although system crises may produce shortterm gains, this very fact leads to demobilization.)

As Figure II indicates, there would be a direct and positive relationship between size and power were it not for the fact that size leads, inevitably, to a diversity of interests, which reduces the ability to motivate people for collective goals. (This is also true for speed of mobilization.) Here is where the boundary debates can assume importance: by isolating the common experiences of those who sell their labor power, and identifying them to potential movement recruits so as to produce greater solidarity. Michael Schwartz (1976:195) has recognized the paradox of size and power. "The group needs a larger membership to succeed; and at the same time, it needs success to grow." However, this process will unravel if the organization cannot solve people's grievances, and/or if it cannot educate members. Many would see the tendency toward bureaucracy or oligarchy as extraordinary and unfortunate.- I see it as quite normal, and potentially useful.

\section{The Process of Bureaucratization}

There has been a long-standing debate within the social movement literature between those who see bureaucratization as inevitable within a successful movement and those who do not. William Gamson (1975), for example, has suggested that groups with a well-developed division of labor and organizational structure are more capable of mobilizing constituencies with widely diverse interests. Charles Tilly and his associates (1975, 1978, 1981) have documented the shift from communally based organizations, which engage in small-scale localized action, to those characteristic of modern industrialized societies, in which

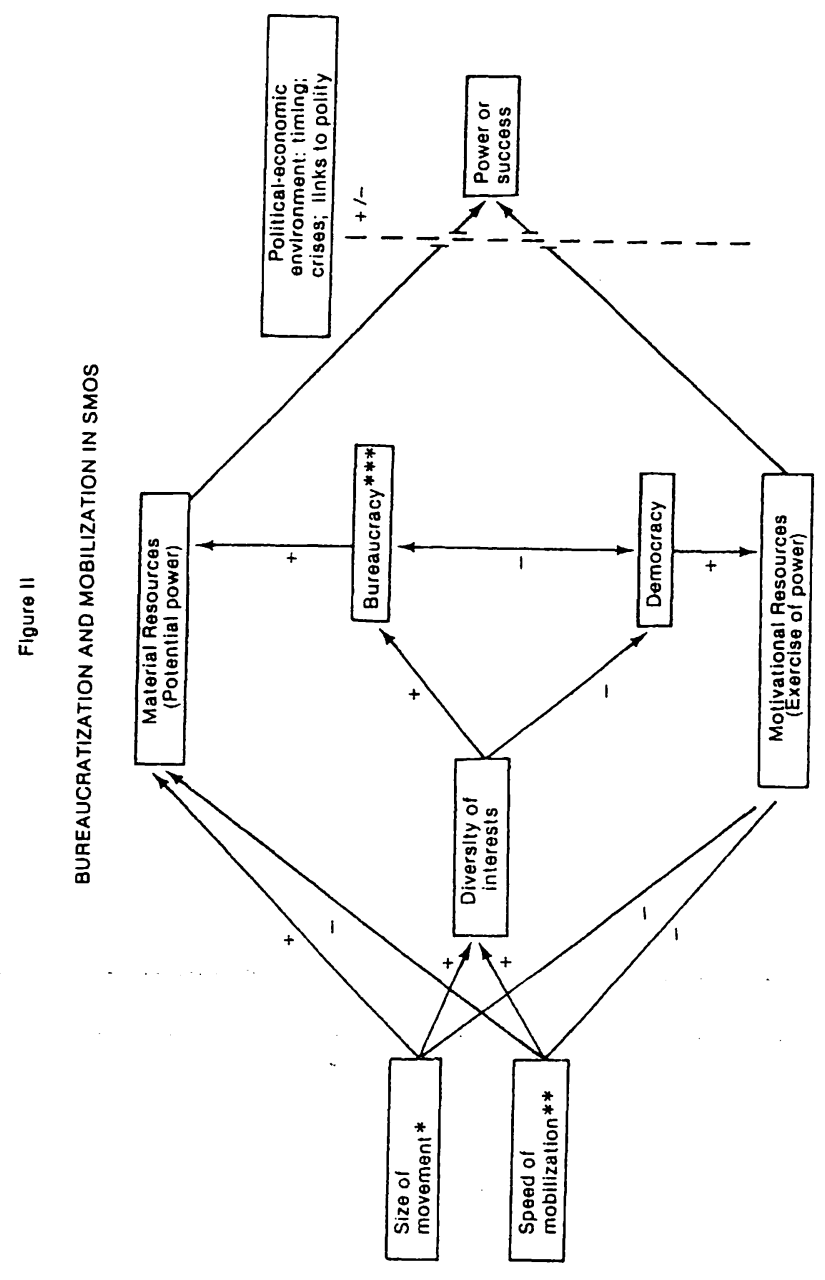


centralized, formally organized movements dominate. Summarizing the position, J. Craig Jenkins (1983:540) has noted:

The growth of industrial capitalism and the building of modern states destroyed the autonomy of small solidary groups and forced claimants to compete in a larger national political arena in which large numbers and bureaucratic structures were keys to success. Furthermore, urbanization and the growth of the mass media reduced the costs of large-scale mobilization, making bureaucratized associations more feasible. Finally, the institutionalization of liberal democracy, especially mass electoral participation, furnished an environment well suited to movement organizations that could mobilize large numbers of supporters.

Those who believe that bureaucratization is not inevitable usually point to small-scale personal growth movements, or note that the civil rights or women's movement grew without a centralized bureaucracy, but they miss an important point: even though different civil rights or women's movements pursued somewhat different specific goals, and of ten represented different constituencies, they still shared a common set of assumptions.

As a group shifts from localized concerns--the very issues that may have drawn people into a movement--to national concerns, bureaucratization may be crucial to the group's success. If a group lacks a centralized hierarchy, or has few links between local leaders and organizations and the national unions or parties, the group's chances of success are lessened. Whether or not a group has a well-developed organizational structure from which to mount a prolonged assault strongly affects its chance of success, and, consequently, the extent to which the organization can count on the loyalties of its members. Figure III summarizes the processes by which a group achieves cohesion and outlines the processes that limit the possibility of success.

In Figure II, we outlined a process whereby size leads to diversity of interests, which leads to bureaucratization (or conversely, negates full democratic decision making), which then enhances the ability of the leadership to mobilize members and gain power. In the case of a large union, this model suggests that in order to exercise or gain power, a group must command some needed material resource. Unions can threaten work stoppages, strikes and boycotts, and their threats may be taken seriously, depending on the size of the organization and the extent to which

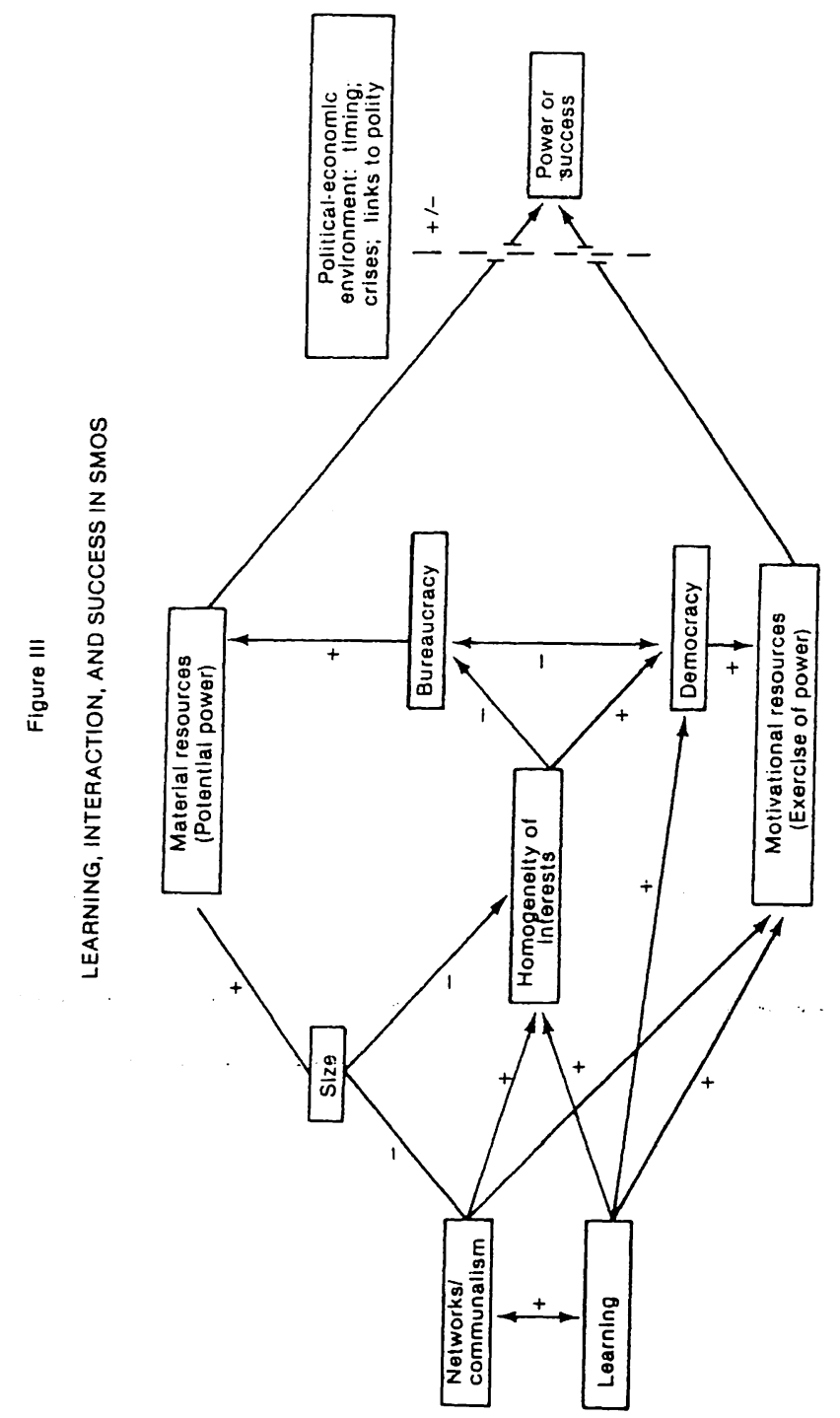


the leadership is able to call the members out, keep them out, or likewise, prevent members from walking off the job. Individualistic interests must be suppressed in favor of an overarching goal, and this is usually accomplished through a centralized or bureaucratic organization.

\section{Organization, Success, and System Crises}

Gamson's $(1975,1980)$ detailed study of groups which have challenged the dominant political-economic order isolated several variables that relate to success. His dependent variable was defined as full acceptance, meaning that the social movement organization was recognized as a central political actor (it made a difference and its concerns were taken into account as, say, were the concerns of Jesse Jackson's Rainbow Coalition during the 1984 Presidential campaign), and that it had actually achieved the goals and objectives laid out by the organization. First, he found that size was positively related to acceptance, though not necessarily to success. Therefore, dominant political parties will try to absorb renegade movements either by coopting the leadership, or through the selective endorsement of the movement's less radical demands. Gamson argued that bureaucratization and centralization were central to success, because most attempts to challenge a given order demand long and sustained political conflict.

Bureaucratic organization provides a solution to the problem of combat readiness--a cadre of reliable workers with coordinated tasks. Its contribution to the management of internal dissent is minimal; bureaucratic groups are at least as likely to experience factional splits as non-bureaucratic ones. But their ability to act quickly also depends on their having solved the problem of internal division. Centralization of power is an organizational device for handling the problem of internal division and providing unity (1975:107-108).

Gamson also found that bureaucratic organizations which narrowed their goals, could of fer members definite resources for participation, and were unruly during periods of political crisis, were most likely to achieve success. Tilly (1978) and Skocpol (1979) have also demonstrated that a group's chances of success are substantially increased during periods of crisis, be they economic or political.

Can a class movement succeed only if it has at its core a solid organization of dedicated members ready to seize upon weaknesses in the political-economic order? Frances Fox Piven and Richard A. Cloward (1977) argue powerfully to the contrary. In their study of Poor People's Movements they have argued that movement organizers who concentrate on building an organization risk the very goals they hope to realize.

During those brief periods in which people are aroused to indignation, when they are prepared to defy the authorities to whom they ordinarily defer. . those who call themselves leaders do not usually escalate the momentum of the people's protests. They do not because they are preoccupied with trying to build and sustain embryonic formal organizations in the sure conviction that these organizations will enlarge and become powerful (283). ${ }^{2}$

Piven and Cloward say, even more precisely, "The poor can create crises but cannot control the response to them" (286). According to them, poor people must seize whatever benefits the moment presents, not waste their precious time and resources building organizations which will, in the long run, be coopted anyway. The American political system is supposed to be particularly vulnerable to mass protests and demonstrations in which people settle for what they can get, rather than holding out for long-term "revolutionary" change. If there is a strategy for movements of the poor, it is to wait for and identify those situations in which the system is particularly vulnerable, and politicians will make concessions. (This is not a bad strategy, especially if the concessions relate to an increased share of the surplus value, which is what class conflict ultimately comes down to. It is a weak strategy, if people cannot sustain continued demands.)

One of Piven and Cloward's main contributions has concerned how protest is institutionally determined and shaped-what is, and is not, permitted--and why the protest of the poor is of ten aimed at very specif ic targets, rather than at what one might think of as social structures. It is aimed at specific people or companies because working men and women "do not experience monopoly capitalism" but the factory, the assembly line, the foreman, the pay packet, and the employer; the people on relief "do not experience American welfare policy," but shabby waiting rooms, overseers, case workers, and the dole (290). This is exactly why education through action, guided by an organization, is so important. 
As Eric Hobsbawm (1984) has pointed out in his masterful summary and critique of Piven and Cloward, what "the situation permits protestors to do depends on how the protesting groups have organized their everyday lives and labor" (290). The unorganized poor can withhold their support from the system, refuse collaboration, and rebel "against the rules and authorities associated with everyday activities" (290). According to Piven and Cloward this localized protest is the most effective. But as Hobsbawm correctly emphasizes, mass protest cannot be an end in itself. Labor unionization or organization in the United States developed out of the mass protests and mobilizations of relatively unorganized workers. Piven and Cloward are right to criticize organizing efforts which get in the way of mobilization, but mistaken in arguing that lasting gains can be achieved without organization. If unionization occurred because of mass protests, workers gained in the years that followed not because they disbanded, but because there were organizations that represented their interests. Organizations sustain people's efforts to change their lives.

I agree with Hobsbawm that the poor, "indeed, any subaltern group, become a subject rather than an object of history only through formalized collectivities" (293). Change does not occur through blind reaction--challenging the system to see how elites respond--but through organized efforts (see Traugott, 1985, for a discussion of the importance of organizations in crystallizing and mobilizing class sentiment). Organizations grounded in people's own experiences, organizations that represent people's interests, have the greatest likelihood of wringing concessions from the state, and winning control of the political and economic system. Organized groups, whether of the poor or the middle classes, have always posed the greatest threat to state power. It is organized protest, today as in the past, that authorities seek to prevent.

\section{POLITICAL IMPLICATIONS}

I have said that class must be conceptualized as structure, ideology, and organization. Ideology is an essential element out of which class is created. It is just as important as structure, or economic position. For a class to realize itself as a class, it must organize, and the struggle between classes begins at this level. If we see class and class struggle as a dynamic process involving these central elements, we can see that the battle for class hegemony must take place on several fronts simultaneously. A class must come to be possessed of a unique ideology and an autonomous organization.

The issue of structure, of whether or not a class can be composed of those occupying unique or very diverse positions in the division of labor, is a more thorny problem. Clearly the dividing line between exploiters and exploited is an important one, but the fact remains that those who sell their labor power, whether factory workers, teachers, or members of a professional managerial class, experience and react to the capitalist system very differently. We might argue that their interests are basically the same, but it remains for people to act in concert before they become a class.

Class, as I have argued, is not static; it grows out of a confrontation with other classes, with "the system." One of the ways in which those who occupy different economic positions in the class structure can become members of a similar class is by developing a comparable ideology and by forging organizational alliances which act in the interests of all wage laborers. This does not happen by magic and it does not happen overnight. If we see the formation of a class as similar to the formation and development of a social movement, we see that a uniform ideology develops from a sustained attempt at change, and that people come to act in the name of the collective, rather than for themselves, through the movement. People must learn to speak and act as one, and this comes about by creatively escalating the battle. Here, class organizations loom large: they are the means by which information is exchanged and new strategies are developed. A centralized, bureaucratic organization is essential for accomplishing these purposes. Ideally, the centralized bureaucracy will be composed of "organic" intellectuals, who act in the name of the class, and who have well-developed mechanisms for continuing the education of the class.

But let us be realistic in asking how classes might be created in American society today. The class organizations that are most readily available to the American people, and which already have some degree of legitimation, are the national political parties, at present in a state of crisis because the margin of victory in recent presidential elections has been so narrow. (I am taking into account the Johnson, Nixon, and Reagan "landslides." The facts are that the change in just a few percentage points would have swung the popular vote to the opposition candidates.) Both parties are eager to make concessions to well-organized constituencies. (We simply have to look at the recent conventions of either the Democrats or Republicans to see that this is true. That some of the concessions were made reluctantly only reinforces the point.) The 
political system itself is vulnerable to change because the percentage of registered voters, and the number of people voting, has declined until we have one of the lowest rates of all the western democratic countries. Massive and sustained voter registration drives, and the constant education of the electorate, is both a viable and necessary strategy.

Jesse Jackson's Rainbow Coalition is one way to bring people together to get concessions from the dominant parties. The endorsements that unions exchange for promised economic benefits are also ways by which to embed class contradictions within the modern state. The answer is not to condemn democratic or reformist politics, but to see participation as a rational way to stage a struggle for control. Revived political parties can be a means for educating the electorate, for creating class consciousness, and furthering the class struggle.

\section{FOOTNOTES}

1. Portions of the following discussion on social class formation come from Scott G. McNall, The Road to Rebellion (Chicago: University of Chicago Press, forthcoming.) See, in particular, Chapter I.

2. My analysis of Piven and Cloward's argument follows that of Hobsbawm (1984b), and the page references are to Hobsbawm's citations.

\section{REFERENCES}

Althusser, Louis

1970 For Marx. New York: Vintage.

Althusser, Louis and Etienne Balibar

1968 Reading Capital. London: New Left Books.

Aminzade, Ron

1981 Class, Politics, and Early Industrial Capitalism: A Study of Mid-Nineteenth Century Toulouse, France. Albany: SUNY Press.

Anderson, Perry

1974 Passages from Antiquity to Feudalism. London: New Lef $\mathrm{t}$ Books.

1980 Arguments Within English Marxism. London: New Left Books.
Barnes, Donna

1984 Farmers in Rebellion: The Rise and Fall of the Southern Farmer's Alliance and People's Party in Texas. Austin: University of Texas Press.

Calhoun, Craig

1982 The Question of Class Struggle: Social Foundations of Popular Radicalism During the Industrial Revolution. Chicago: University of Chicago Press.

Clawson, Mary Ann

1985 "Fraternal Orders and Class Formation in the NineteenthCentury United States." Comparative Studies in Society and History 27:672-695.

Ehrenreich, John and Barbara Ehrenreich

1978 "The Professional Managerial Class." Pp. 5-45 in Pat Walker, (ed.), Between Labour and Capital. Montreal: Black Rose Books.

Fireman, Bruce and William Gamson

1979 "Utilitarian Logic in the Resource Mobilization Perspective." Pp. 8-44 in John D. McCarthy and Mayer N. Zald, (eds.), The Dynamics of Social Movements. Cambridge: Winthrop Publishers.

Gamson, William

1975 The Strategy of Social Protest. Homewood, Illinois: Dorsey.

1980 "Understanding the Careers of Challenging Groups: A Comment on Goldstone." American Journal of Sociology 85:1043-1060.

Goodwyn, Lawrence

1978 The Populist Moment. New York: Oxford University Press. Granovetter, Mark

1985 "Economic Action and Social Structure: The Problem of Embeddedness." American Journal of Sociology 91:481-510.

Gutman, Herbert

1973 "Work, Culture, and Society in Industrializing America, 1815-1919." American Historical Review 78:531-588.

Hahn, Steven

1983 The Roots of Southern Populism: Yeoman Farmers and Transformation of the Georgia Upcountry, 1850-1890. New York: Oxford University Press.

Hannigan, John A

1985 "Alain Touraine, Manuel Castells and Social Movement Theory: A Critical Appraisal." The Sociological Quarterly 26: $435-454$. 
Hobsbawm, Eric

1984a "The Making of the Working Class, 1870-1914." Pp. 194 213 in Eric Hobsbawm, (ed.), Workers: Worlds of Labor New York: Pantheon.

1984b "Should Poor People Organize." Pp. 282-296 in Eric Hobsbawm, (ed.), Workers: Worlds of Labor. New York Pantheon.

Jenkins, J. Craig

1983 "Resource Mobilization Theory and the Study of Social Movements." Annual Review of Sociology 4:527-553.

Klandermans, Bert

1984 "Social-Psychological Expansions of Resource Mobilization Theory." American Sociological Review 49:583-600.

Levine, Rhonda

1985 "Marxism, Sociology, and Neo-Marxist Theories of the Marx, Karl State." Current Perspectives in Social Theory 6:149-168.

1919 The Eighteenth Brumaire of Louis Bonaparte. Chicago: McAdam, Doug Charles Kerr. (Originally published in 1852).

1983 "Tactical Innovation and the Pace of Insurgency." American Sociological Review 48:735-753.

McCarthy, John D. and Mayer N. Zald

1973 The Trend of Social Movements. New York: General Learning.

McKenzie, Gavin

1982 "Class Boundaries and the Labour Process." In Anthony Giddens and Gavin McKenzie, (eds.), Social Class and the Division of Labour. New York: Cambridge University Press:

Meiksins, Peter

1986 "Beyond the Boundary Question." New Left Review 157:101-120.

Moore, Barrington

1978 Injustice: The Social Basis of Obedience and Revolt. White Plains, New York: Sharpe.

Oberschall, Anthony

1978 "Theories of Social Conflict." Annual Review of Sociology 4:291-315.

Offe, Claus

1985 Disorganized Capitalism. Cambridge: MIT Press.
Olson, Mancur

1965 The Logic of Collective Action: Public Goods and the Theory of Groups. Cambridge: Harvard University Press.

\section{Oppenheimer, Martin}

1985 White Collar Proletariat. New York: Monthly Review Press.

Piven, Frances Fox and Richard A. Cloward

1977 Poor People's Movements: Why They Succeed, How They Fail. New York: Pantheon.

Porpora, Douglas V.

1985 "The Role of Agency in History: The AlthusserThompson-Anderson Debate." Current Perspectives in Social Theory 6:219-241.

Poulantzas, Nicos

1978 State, Power, Socialism. London: New Left Books.

Prezworski, Adam

1977 "The Process of Class Formation from Karl Kautsky's The Class Struggle to Recent Debates." Politics and Society 7:64-85.

Quadagno, Jill

1984 "Welfare Capitalism and the Social Security Act of 1935." American Sociological Review 49:632-647.

Roy, William G.

1984 "Class Conflict and Social Change in Historical Perspective." Annual Review of Sociology 10:483-506.

Schwartz, Michael

1976 Radical Protest and Social Structure: The Southern Farmers' Alliance and Cotton Tenancy, 1880-1890. New York: Academic Press.

Sewell, William H., Jr.

1985 "Ideologies and Social Revolutions: Reflections on the French Case." The Journal of Modern History 57:57-85.

Skocpol, Theda

1979 States and Revolutions. New York: Cambridge University Press.

1980 "Political Response to Capitalist Crisis: Neo-Marxist Theories of the State and the Case of the New Deal." Politics and Society 10:155-202.

Snow, David, Burke Rochford, Steven Worden, and Robert Benford

1986 "Frame Alignment and Mobilization." American Sociological Review 51:464-481. 
Mid-American Review of Sociology

Thompson, E.P.

1963 The Making of the English Working Class. New York: Vintage.

1978 The Poverty of Theory. New York: Monthly Review Press. Tilly, Charles

1978 From Mobilization to Revolution. Reading, MA: AddisonWesley.

Tilly, Charles and Louise Tilly

1981 Collective Action and Class Conflict. Beverly Hills, CA: Sage.

Tilly, Charles, Louise Tilly, and R. Tilly

1975 The Rebellious Century. Cambridge, MA: Harvard University Press.

Traugott, Mark

1985 Armies of the Poor: Determinants of Working-Class Participation in the Parisian Insurrection of June 1848. Princeton, N.J.: Princeton University Press.

Wright, Erik O.

1984 "A General Framework for the Analysis of Class Structure." Politics and Society 13:383-423.

1985 Classes. London: Verso Books, 1985.

\section{WHAT'S NEW ABOUT THE "NEW SOCIAL MOVEMENTS"? CONTINUITIES AND DISCONTINUITIES WITH THE SOCIALIST PROJECT}

\author{
Peter Kivisto \\ Augustana College
}

Mid-American Review of Sociology, Vol. XI, No. 2:29-44

Since the 1960s, social theorists have sought to explicate factors that contributed to the emergence of the New Left in North America and Western Europe and to the "new social movements" that arose during this tumultuous decade (see, for example, Alberoni, 1984; Birnbaum, 1969; Gamson, 1975; Gorz, 1973; Gouldner, 1979; Habermas, 1970 and 1975; Jenkins, 1986; Klandermans and Oegema, 1987; Oberschall, 1978; Offe, 1984 and 1985; Tilly, 1978; Touraine, 1971a, 1971b, and 1981; Useem, 1975). There are, as Cohen (1983:97) suggests, "compelling reasons for a renewed reflection on the significance and potentials of social movements." In no small part, this is because these movements served to dispel the conviction that advanced industrial societies had arrived at a stage that marked the "end of ideology," as they reflected instead conflictual tendencies in those societies. This paper explores questions concerning the relationship of these movements to socialism. It does so by reviewing issues raised both in theoretic discourse and in concrete instances of these new contestatory actors.

Two approaches to the study of social movements can be distinguished: resource mobilization theory (Jenkins, 1985; McAdam, 1982; McCarthy and Zald, 1973; Oberschall, 1973; Perrow, 1979) and what might be defined, albeit imprecisely and in a more generalized sense, as critical theory. The former emerged out of and in response to collective behavior theory. While there are significant variations within the general theoretic framework, those working within its parameters agree that social movements are rational, the underlying structural sources of conflict are ubiquitous features of contemporary societies, and that movement mobilization occurs with the proper confluence of resources, organization, and opportunities (Jenkins, 1983:528). These domain assumptions are intended to contest earlier psychologistic theories that saw social movements as pathological evidences of strain (e.g., Smelser, 1963). Resource mobilization theory implicitly argues that social movements can be far more pervasive than earlier theories would suggest. 